\title{
Simultaneous Determination of Sulphamethoxazole and Trimethoprim in Binary Mixtures and in Tablet Using Derivative Spectrophotometry
}

\author{
Khaleda H. Al-Saidi and Marwa S. Yonis \\ Department of Chemistry, College of Science, Al-Nahrain University, Al-Jaderia, \\ Baghdad-Iraq.
}

\begin{abstract}
Derivative spectrophotometric (first, second, third and fourth derivative) were developed for the determination of Sulphamethoxazole(SMX) and trimethoprim (TMP)antibiotic binary mixture by applying zero-crossing technique for pure synthetic mixture while simultaneous determination of (SMX) and (TMP) in tabletsusing $\mathrm{D}^{4}$ at waveleanth $257.8 \mathrm{~nm}$ and $251.5 \mathrm{~nm}$ for (SMX) and (TMP) the correlation coefficient of calibration curves were 0.9992 and 0.9995 . Linearity is maintained within a wide concentration range from 2.00 to $25.00 \mathrm{mg} / \mathrm{l}$, with relative error $(-0.11$ and 0.60$)$ the LOD $(0.360$ and $0.382 \mathrm{mg} / \mathrm{L})$ and LOQ and $(1.200$ and $1.275 \mathrm{mg} / \mathrm{L})$ respectively.No interference found between both determined and those of matrices. A good accuracy and precision of simultaneous determination of (SMX), and (TMP) were confirmed by statistical analysis.The percentage recovery of the individual drugs under the established conditions is ranged from $97.23 \%$ to $102.13 \%$. This method was compared with the British pharmacopoeiamethodusing $\mathrm{F}$ test. The procedures do not require any separation step.
\end{abstract}

Keywords: Sulphamethoxazole, Trimethoprim, Co-trimoxazole, Derivative spectrophotometry.

\section{Introduction}

\section{Sulphamethoxazole}

Sulphamethoxazole (SMX), 4-Amino-N(5-methylisoxazol-3-yl) benzene sulphonamide, $\left(\mathrm{C}_{10} \mathrm{H}_{11} \mathrm{~N}_{3} \mathrm{O}_{3} \mathrm{~S}\right),(1-\mathrm{a})$, is white, or almost white crystalline powder with molecular weight $253.3 \mathrm{~g} / \mathrm{mole}$, practically insoluble in water, freely soluble in acetone, sparingly soluble in alcohol, slightly soluble in ether. It dissolves in dilute sodium hydroxide solution. ${ }^{(1)}$

\section{Trimethoprim}

Trimethoprim (TMP), 5-(3,4,5-Trimethoxy benzyl) pyrimidine-2,4-diamine, $\left(\mathrm{C}_{14} \mathrm{H}_{18} \mathrm{~N}_{4} \mathrm{O}_{3}\right)$, (1-b),

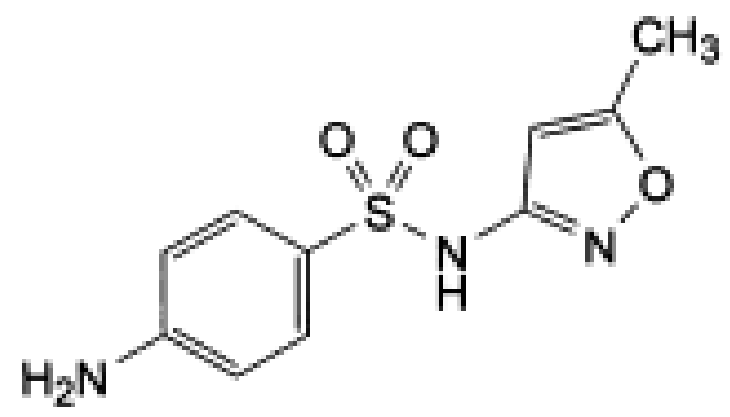

(a)<smiles>COc1cc(Cc2cnc(N)nc2N)cc(OC)c1OC</smiles>

(b)

Fig.(1) Structure formulaof

(a) SMX (b)TMP.

The combination of (SMX) and (TMP) are used for the treatment of infections caused by susceptible bacterial organisms, follows the practical application of the principle that if two drugs act on sequential steps in the pathway of an obligate enzymatic reaction in bacteria, the result of their combination will be supraadditive $^{(2)}$. The optimal ratio of the two agents for their synergistic activity has been found to be $5: 1{ }^{(3)}$

Various methods have been reported for the simultaneous determination of the combination of SMX and TMP in pharmaceutical formulations and biological fluids, such as (HPLC) $)^{(4-6)}$, Thin layer chromatography $(\text { TLC })^{(7)}$, capillary zone electrophoresis method ${ }^{(8)}$, Voltametric methods ${ }^{(9-10)}$, Spectrophotometric methods ${ }^{(11-13)}$, 
and Derivative spectrophotometric methods ${ }^{(14-16)}$.

Derivative spectrophotometry is an analytical technique of great utility for resolving some mixture of compound with overlapping $\operatorname{spectra}^{(17-20)}$. In this work, new methods were used to develop spectrophotometric methods for the simultaneous determination of the component of these binary mixtures without prior separation.

\section{Experimental}

\section{Instruments and Equipment:}

Double-beam UV-Visible spectrophotometer model (UV-1650 PC) SHIMADZO (Japan), interfaced with computer via a SHIMADZU UV probe data system program (Version 1.10), using $1.00 \mathrm{~cm}$ quartz cells, (W. Germany), Sartorius Handy 4digits Analytical Balance.

\section{Chemicals:}

Standard drugs: (SMX) and (TMP) were purchased from the State Company of Drug Industries and Medical Appliances (IRAQSDI- Samara) and the mixture of sulphamethoxazole with (TRIMOL) tablets from (Julphar-UAE) were purchased from the local market, sodium hydroxide obtained from (BDH). All drugs were used as working standards without further purification.

\section{Preparation of Stock and working Standard Solutions}

1- $(0.1 \mathrm{M})$ sodium hydroxide was prepared by dissolving an accurate amounts $(4.00 \mathrm{~g})$ of sodium hydroxide in (1L) distilled water.

2- Stock solutions of $(250 \mathrm{mg} / \mathrm{l})$ standard were prepared by dissolving an accurate amounts $(25.00 \mathrm{mg})$ of the studied drugs in sodium hydroxide $(0.1 \mathrm{M})$ in $100 \mathrm{ml}$ volumetric flask, the solutions are then made up to mark with sodium hydroxide.

3- Two series of pure single standard (2-30mg/L) was prepared by diluting Stock solution with $(0.1 \mathrm{M})$ sodium hydroxide.

4- Solutions for binary mixtures of standard drugs (SMX) and (TMP) solutions were prepared by two series.
First series of mixture solutions were prepared by using a fixed concentration of $(20 \mathrm{mg} / \mathrm{L})$ for(SMX) with different concentrations $(2,4,6,8,10,15,20 \quad$ and $25 \mathrm{mg} / \mathrm{L}$ ) of (TMP), while the second series of mixture contains a fixed concentration (4 $\mathrm{mg} / \mathrm{L})$ of (TMP) with different concentration of $(2,4,6,8,10,15,20$ and $25 \mathrm{mg} / \mathrm{L})$ of (SMX).

5- $(250 \mathrm{mg} / \mathrm{l})$ stock solutions of interferences were prepared by dissolving an accurately weighed amount $(0.0125 \mathrm{~g})$ of each (starch, gelatin, magnesium setrate, avecil, sucrose) in $50 \mathrm{~mL}$ of $0.1 \mathrm{M} \mathrm{NaOH}$, the other working solutions were prepared by the serial dilution.

\section{Preparation of pharmaceuticals samples}

All contents of 10 tablets of the pharmaceutical Co-Trimoxazole (MITHO PRIM-400 and TRIMOL) were weighted and grinded to fine powder. Accurate weight $(1 / 10)$ of one tablet $(0.0519 \mathrm{~g})$ and $(0.0647 \mathrm{~g})$ of (MITHOPRIM-400 and TRIMOL) respectively. Which was dissolved by $100 \mathrm{mlof}$ $(0.1 \mathrm{M})$ sodium hydroxide then filtrated, the clear solution were taken and filed up to $100 \mathrm{ml}$. The resultant solution may be contained $400 \mathrm{mg} / \mathrm{L}(\mathrm{SMX})+80 \mathrm{mg} / \mathrm{L}$ (TMP) the other working solutions were prepared by the serial dilution method.

\section{Results and Discussion}

The absorption spectra of SMX and TMP under certain experimental conditions are shown in Fig.(2-a). As can be seen, the maximum wavelengths of two compounds are close to each other and their spectra overlap, therefore, determination of SMX and TMP in the presence of each other is impractical by classical spectrophotometry, and derivative spectrophotometry can be used in this case. The zero crossing method applied on the first derivative $\left(\mathrm{D}^{1}\right)$ to determine the concentration of SMX at valley $288 \mathrm{~nm}$ as shown in Fig.(2-b). On the other hand the second derivative cannot be used to determine neither SMX nor TMP as can be seen in Fig.(2-c). The Fig.(2-d) shows that both compounds can be determined in the third derivative; SMX at valley $251.4 \mathrm{~nm}$, and TMP at valley $258.6 \mathrm{~nm}$. And from the fourth derivative SMX can be 
determined at valley $246.2 \mathrm{~nm}$, and TMP at valley $251.5 \mathrm{~nm}$ as shown in Fig.(2-e). All these methods and there equations, slope, concentration rang, correlation coefficient and the relative errors for the mixtures containing 5:1 of each drug were listed in Table (1).

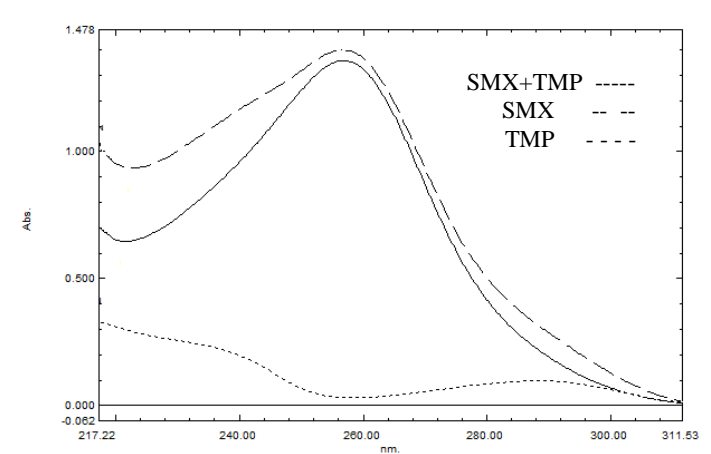

Fig. (2-a)

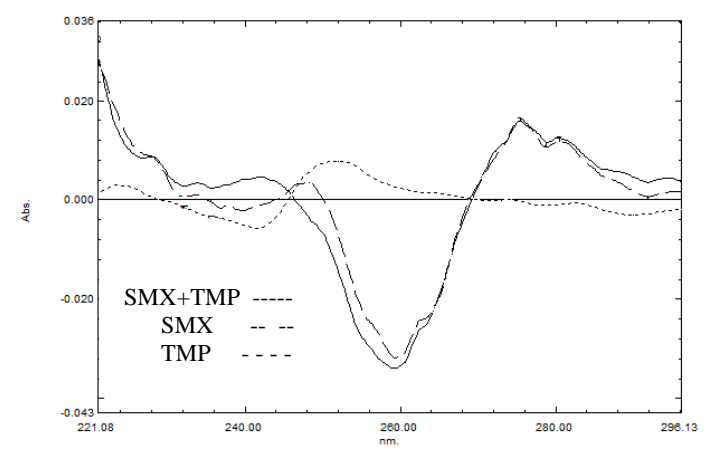

Fig. $(2-c)$

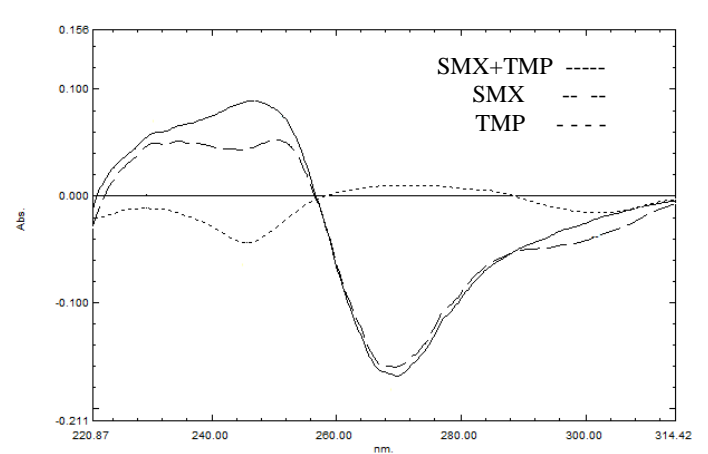

Fig. (2-b)

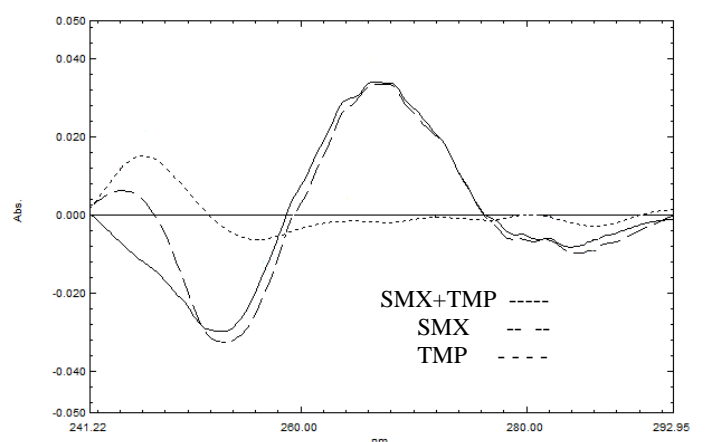

Fig. (2-d)

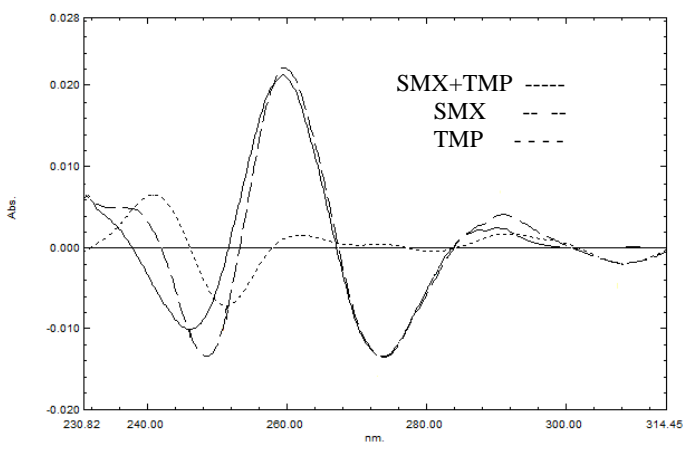

Fig. (2-e)

Fig. (2) Spectra of $20 \mathrm{mg} / \mathrm{L} \mathrm{SMX,} 4 \mathrm{mg} / \mathrm{L} \mathrm{TMP}$ and a mixture of $20 \mathrm{mg} / \mathrm{L} \mathrm{SMX}+4 \mathrm{mg} / \mathrm{L} \mathrm{TMP}$. $a$ - Normal spectrum $b$-First derivative $c$-Second derivative $d$-Third derivative $e$-Fourth derivative. 
Table (1)

The Methods used for determination the binary mixture of SMX and TMP.

\begin{tabular}{|c|c|c|c|c|c|c|c|c|}
\hline Drug & \multicolumn{2}{|c|}{ Method } & Equation & Slop & $\begin{array}{c}\text { Relative } \\
\text { error for } \\
5: 1\end{array}$ & $\boldsymbol{R}$ & $\begin{array}{c}L O D \\
\mu g / m L\end{array}$ & $\underset{\mu g / m L}{L O Q}$ \\
\hline \multirow{4}{*}{$S M X$} & $\mathrm{D}^{1}$ & $\mathrm{~V}=288.0$ & $Y=-0.00283 \times+0.00155$ & -0.00283 & -1.46 & 0.9996 & 0.750 & 2.499 \\
\hline & $\mathrm{D}^{3}$ & $V=251.4$ & $Y=-0.00139 \times-0.00041$ & -0.00139 & -1.90 & 0.9981 & 0.505 & 1.684 \\
\hline & $\mathrm{D}^{4}$ & $V=246.2$ & $Y=-0.00047 \times-0.00118$ & -0.00047 & -0.85 & 0.9989 & 0.395 & 1.317 \\
\hline & $\mathrm{D}^{4}$ & $P=257.8$ & $Y=0.00095 x+0.00011$ & 0.00095 & -0.11 & 0.9992 & 0.360 & 1.200 \\
\hline \multirow{3}{*}{ TMP } & $\mathrm{D}^{3}$ & $V=258.6$ & $Y=-0.00114 x+0.00013$ & -0.00114 & -1.45 & 0.9995 & 0.814 & 2.712 \\
\hline & $\mathrm{D}^{4}$ & $V=251.5$ & $Y=-0.00179 x+0.00028$ & -0.00179 & 0.60 & 0.9995 & 0.382 & 1.275 \\
\hline & $\overline{D^{4}}$ & $P=237.6$ & $Y=0.00096 \times+0.00135$ & 0.00096 & -1.70 & 0.9995 & 0.751 & 2.503 \\
\hline
\end{tabular}

First derivative spectrum of SMX and TMP which contain a suitable wavelength for measuring SMX at $288 \mathrm{~nm}$ when the absorbance of TMP equal zero as shown in Fig.(3), calibration curves of $\mathrm{D}^{1}$ for standards SMX and TMP solutions $(2-25 \mathrm{mg} / \mathrm{L})$ gave a linear equation and the correlation coefficient and slop were listed in Table (1). The recovery and relative error of the pure SMX and the synthetic mixtures were tabulated in Table (2). Third derivative spectrum which contain a suitable wavelength for measuring SMX by applying zero crossing at $251.4 \mathrm{~nm}$ shown in Fig.(4), the recovery and relative error of the pure SMX and the synthetic mixtures were tabulated in Table (3). Fourth derivative zero crossing spectrums of SMX at valley $246.2 \mathrm{~nm}$ and peak $257.8 \mathrm{~nm}$ is shown in Fig.(5), the recovery and relative error are listed in Table (4) and (5) respectively.

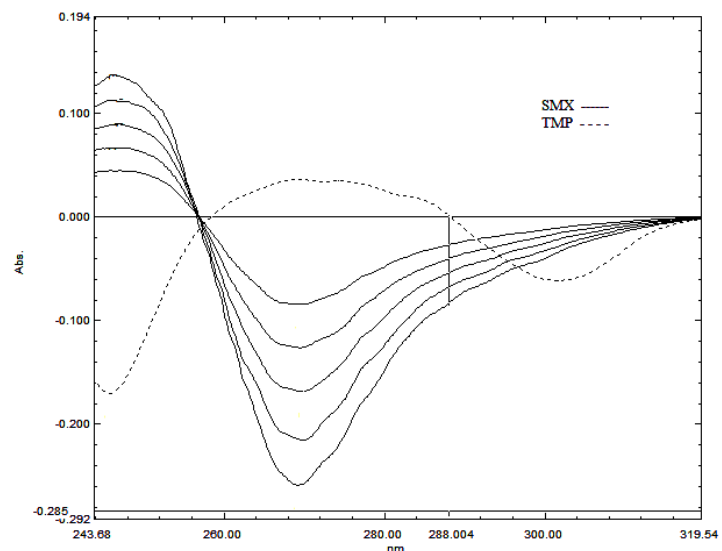

Fig.(3) First derivative zero crossing of (4-25) $\mathrm{mg} / \mathrm{L} \mathrm{SMX}$ with(4)mg/L TMP.
Table (2)

The relative error and recovery of $S M X$ in the presence of TMP using $D^{1}$ spectrum zero crossing at valley $288 \mathrm{~nm}$.

\begin{tabular}{|c||c||c||c||}
\hline $\begin{array}{c}\text { SMX and TMP } \\
\text { mixtures }\end{array}$ & $\begin{array}{c}\text { SMX } \\
\text { found } \\
\text { mg/L }\end{array}$ & $\begin{array}{c}\text { Relative } \\
\text { error\% }\end{array}$ & $\begin{array}{c}\text { Recovery } \\
\text { \% }\end{array}$ \\
\hline \hline 30 SMX+0 TMP & $\mathbf{3 0 . 2 1 6}$ & $\mathbf{0 . 7 2}$ & 100.72 \\
\hline \hline 20 SMX+0 TMP & $\mathbf{1 9 . 4 0 1}$ & $\mathbf{- 3 . 0 0}$ & 97.01 \\
\hline \hline 10 SMX+0 TMP & $\mathbf{1 0 . 0 0 8}$ & $\mathbf{0 . 0 8}$ & 100.08 \\
\hline \hline 4 SMX+0 TMP & $\mathbf{3 . 8 9 4}$ & $\mathbf{- 2 . 6 5}$ & 97.35 \\
\hline \hline 15 SMX+4 TMP & $\mathbf{1 4 . 6 8 8}$ & $\mathbf{- 2 . 0 8}$ & 97.92 \\
\hline \hline 20 SMX+4 TMP & $\mathbf{1 9 . 7 0 9}$ & $\mathbf{- 1 . 4 6}$ & 98.55 \\
\hline \hline 25 SMX+4 TMP & $\mathbf{2 5 . 4 4 8}$ & $\mathbf{1 . 7 9}$ & 101.79 \\
\hline \hline $20 \mathrm{SMX+2} \mathrm{TMP}$ & $\mathbf{2 0 . 0 6 8}$ & $\mathbf{0 . 3 4}$ & 100.34 \\
\hline \hline 20SMX+4 TMP & $\mathbf{1 9 . 7 0 9}$ & $\mathbf{- 1 . 4 6}$ & 98.55 \\
\hline \hline 20SMX+6 TMP & 19.709 & -1.46 & 98.55 \\
\hline
\end{tabular}

* Each concentration represents an average of at least three measurements.

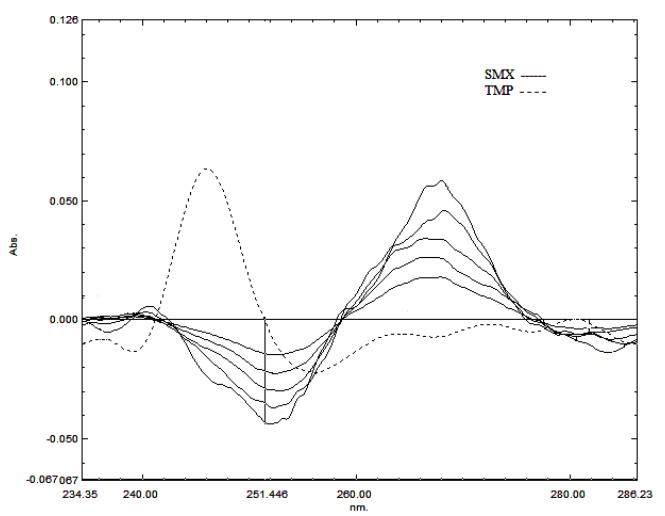

Fig.(4) Third derivative zero crossing of

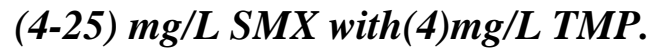


Table (3)

The relative error and recovery of $S M X$ in the presence of TMP using $D^{3}$ Spectrum zero crossing at valley $251.4 \mathrm{~nm}$.

\begin{tabular}{||c||c||c||c||}
\hline $\begin{array}{c}\text { SMX and TMP } \\
\text { mixtures }\end{array}$ & $\begin{array}{c}\text { SMX } \\
\text { found } \\
\boldsymbol{m} \boldsymbol{g} / \mathbf{L}\end{array}$ & $\begin{array}{c}\text { Relative } \\
\text { error\% }\end{array}$ & $\begin{array}{c}\text { Recovery } \\
\text { \% }\end{array}$ \\
\hline \hline 30 SMX+0 TMP & $\mathbf{2 9 . 9 3 7}$ & $\mathbf{- 0 . 2 1}$ & 99.79 \\
\hline \hline 20 SMX+0 TMP & $\mathbf{1 9 . 5 8 1}$ & $\mathbf{- 2 . 1 0}$ & 97.91 \\
\hline \hline 10 SMX+0 TMP & $\mathbf{9 . 7 8 6}$ & $\mathbf{- 2 . 1 4}$ & 97.86 \\
\hline \hline 4 SMX+0 TMP & $\mathbf{4 . 1 1 2}$ & $\mathbf{2 . 8 0}$ & 102.80 \\
\hline 15 SMX+4 TMP & $\mathbf{1 4 . 7 3 1}$ & $\mathbf{- 1 . 7 9}$ & 98.21 \\
\hline \hline 20 SMX+4 TMP & $\mathbf{1 9 . 6 2 1}$ & $\mathbf{- 1 . 9 0}$ & 98.11 \\
\hline \hline 25 SMX+4 TMP & $\mathbf{2 4 . 5 1 1}$ & $\mathbf{- 1 . 9 6}$ & 98.04 \\
\hline \hline 20SMX+2TMP & $\mathbf{2 0 . 3 1 9}$ & $\mathbf{1 . 6 0}$ & 101.60 \\
\hline \hline 20SMX+4TMP & $\mathbf{1 9 . 6 2 1}$ & $\mathbf{- 1 . 9 0}$ & 98.11 \\
\hline \hline 20SMX+6TMP & 19.621 & -1.90 & 98.11 \\
\hline \hline
\end{tabular}

*Each concentration represents an average of at least three measurements.

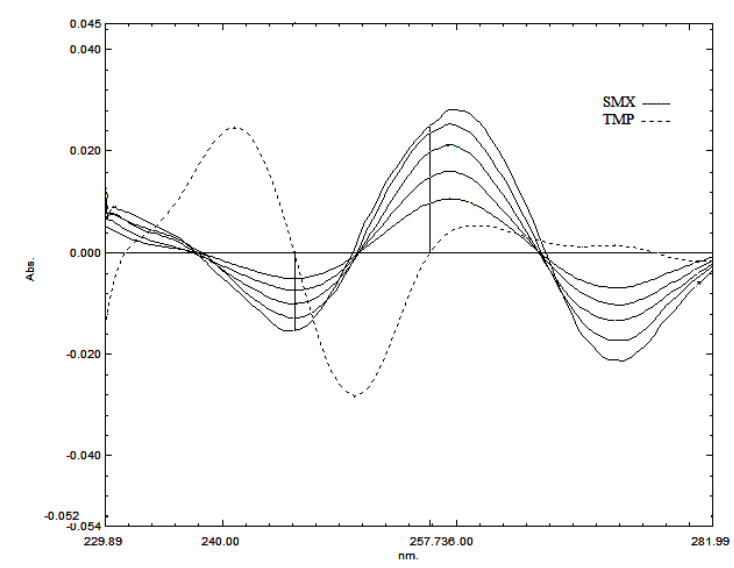

Fig. (5) Fourth derivative zero crossing of (4-25) $\mathrm{mg} / \mathrm{L} \mathrm{SMX}$ with (4)mg/L TMP.
Table (4)

The relative error and recovery of $S M X$ in the presence of TMP using $D^{4}$ spectrum zero crossing at valley $246.2 \mathrm{~nm}$.

\begin{tabular}{|l||c||c||c||}
\hline $\begin{array}{c}\text { SMX and TMP } \\
\text { mixtures }\end{array}$ & $\begin{array}{c}\text { SMX } \\
\text { found }^{*} \\
\text { mg/L }\end{array}$ & $\begin{array}{c}\text { Relative } \\
\text { error\% }\end{array}$ & $\begin{array}{c}\text { Recovery } \\
\text { \% }\end{array}$ \\
\hline \hline 30 SMX+0 TMP & $\mathbf{2 9 . 7 6 2}$ & $\mathbf{- 0 . 7 9}$ & 99.21 \\
\hline \hline 20 SMX+0 TMP & $\mathbf{1 9 . 8 1 7}$ & $\mathbf{- 0 . 9 1}$ & 99.09 \\
\hline \hline 10 SMX+0 TMP & $\mathbf{9 . 7 5 6}$ & $\mathbf{- 2 . 4 4}$ & 97.56 \\
\hline 4 SMX+0 TMP & $\mathbf{3 . 9 2}$ & $\mathbf{- 2 . 0 0}$ & 98.00 \\
\hline 15 SMX+4 TMP & $\mathbf{1 4 . 7 9 3}$ & $\mathbf{- 1 . 3 8}$ & 98.62 \\
\hline 20 SMX+4 TMP & $\mathbf{1 9 . 8 2 9}$ & $\mathbf{- 0 . 8 5}$ & 99.15 \\
\hline \hline 25 SMX+4 TMP & $\mathbf{2 5 . 4 5 4}$ & $\mathbf{1 . 8 2}$ & 101.82 \\
\hline \hline 20SMX+2TMP & $\mathbf{1 9 . 8 2 9}$ & $\mathbf{- 0 . 8 5}$ & 99.15 \\
\hline \hline 20SMX+4TMP & $\mathbf{1 9 . 8 2 9}$ & $\mathbf{- 0 . 8 5}$ & 99.15 \\
\hline \hline 20SMX+6TMP & 19.829 & -0.85 & 99.15 \\
\hline
\end{tabular}

*Each concentration represents an average of at least three measurements.

Table (5)

The relative error and recovery of $S M X$ in the presence of TMP using $D^{4}$ spectrum zero crossing at peak $257.8 \mathrm{~nm}$.

\begin{tabular}{||c||c||c||c||}
\hline $\begin{array}{c}\text { SMX and TMP } \\
\text { mixtures }\end{array}$ & $\begin{array}{c}\text { SMX } \\
\text { found } \\
\text { mg/L }\end{array}$ & $\begin{array}{c}\text { Relative } \\
\text { error\% }\end{array}$ & $\begin{array}{c}\text { Recovery } \\
\text { \% }\end{array}$ \\
\hline \hline 25 SMX+0 TMP & $\mathbf{2 5 . 1 4 5}$ & $\mathbf{0 . 5 8}$ & 100.58 \\
\hline \hline 20 SMX+0 TMP & $\mathbf{1 9 . 8 6 9}$ & $\mathbf{- 0 . 6 6}$ & 99.35 \\
\hline 10 SMX+0 TMP & $\mathbf{9 . 8 9 9}$ & $\mathbf{- 1 . 0 1}$ & 98.99 \\
\hline \hline 4 SMX + 0 TMP & $\mathbf{4 . 0 8 5}$ & $\mathbf{2 . 1 3}$ & 102.13 \\
\hline \hline 15 SMX+4 TMP & $\mathbf{1 4 . 6 8 8}$ & $\mathbf{- 2 . 0 8}$ & 97.92 \\
\hline \hline 20 SMX+4 TMP & $\mathbf{1 9 . 9 7 7}$ & $\mathbf{- 0 . 1 1}$ & 99.89 \\
\hline \hline 25 SMX+4 TMP & $\mathbf{2 5 . 2 6 6}$ & $\mathbf{1 . 0 6}$ & 101.06 \\
\hline \hline 20SMX+2TMP & $\mathbf{1 9 . 9 7 7}$ & $\mathbf{- 0 . 1 1}$ & 99.89 \\
\hline \hline 20SMX+4TMP & $\mathbf{1 9 . 9 7 7}$ & $\mathbf{- 0 . 1 1}$ & 99.89 \\
\hline \hline 20SMX+6TMP & 19.977 & -0.11 & 99.89 \\
\hline
\end{tabular}

*Each concentration represents an average of at least three measurements.

Third derivative spectrum of trimethoprim TMP and sulphamethoxazole SMX which contains a suitable wavelength for measuring TMP at $258.6 \mathrm{~nm}$ when the absorbance of SMX equal zero as shown in Fig.(6), 
calibration curves of $\mathrm{D}^{3}$ for standards TMP and SMX solutions $(2-30 \mathrm{mg} / \mathrm{L})$ gave a linear equation and the correlation coefficient and slop were listed in Table (1). The recovery and relative error of the pure TMP and the synthetic mixtures were tabulated in Table (6). Fourth derivative zero crossing spectrums of TMP at valley $251.5 \mathrm{~nm}$ and peak $237.6 \mathrm{~nm}$ is shown in Fig.(7), the recovery and relative error are listed in Table (7) and (8) respectively.

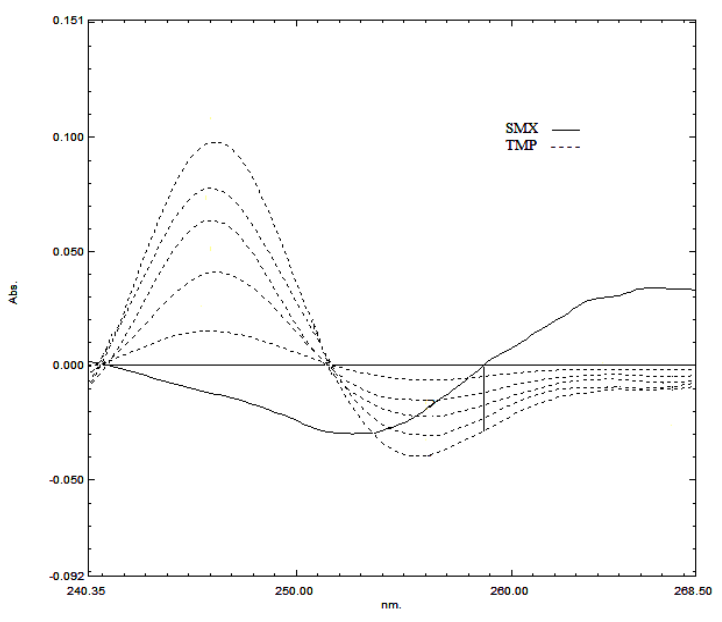

Fig.(6) Third derivative zero crossing of (4-25) mg/LTMP with(20)mg/L SMX.

Table (6)

The relative error and recovery of TMP in the presence of $S M X$ using $D^{3}$ spectrum zero crossing at valley $258.6 \mathrm{~nm}$.

\begin{tabular}{||c||c|c||c||}
\hline $\begin{array}{c}\text { TMP and SMX } \\
\text { mixtures }\end{array}$ & $\begin{array}{c}\text { TMP } \\
\text { found } \\
\text { mg/L }\end{array}$ & $\begin{array}{c}\text { Relative } \\
\text { error\% }\end{array}$ & $\begin{array}{c}\text { Recovery } \\
\text { \% }\end{array}$ \\
\hline \hline 30 TMP+0 SMX & $\mathbf{2 9 . 5 3 7}$ & $\mathbf{- 1 . 5 4}$ & 98.46 \\
\hline \hline 20 TMP+0 SMX & $\mathbf{2 0 . 0 1 2}$ & $\mathbf{0 . 0 6}$ & 100.06 \\
\hline \hline 10 TMP+0 SMX & $\mathbf{9 . 7 3 6}$ & $\mathbf{- 2 . 6 4}$ & 97.36 \\
\hline \hline 4 TMP + 0 SMX & $\mathbf{3 . 9 3 7}$ & $\mathbf{- 1 . 5 8}$ & 98.43 \\
\hline \hline 4 TMP +15SMX & $\mathbf{3 . 8 9 2}$ & $\mathbf{- 2 . 7 0}$ & 97.30 \\
\hline \hline 4 TMP +20SMX & $\mathbf{3 . 9 4 2}$ & $\mathbf{- 1 . 4 5}$ & 98.55 \\
\hline \hline 4 TMP +25SMX & $\mathbf{4 . 0 3 1}$ & $\mathbf{0 . 7 7}$ & 100.78 \\
\hline \hline 2 TMP+20 SMX & $\mathbf{1 . 9 7 4}$ & $\mathbf{- 1 . 3 0}$ & 98.70 \\
\hline \hline 4 TMP+20 SMX & $\mathbf{3 . 9 4 2}$ & $\mathbf{- 1 . 4 5}$ & 98.55 \\
\hline \hline 6 TMP+20 SMX & 6.108 & 1.80 & 101.80 \\
\hline
\end{tabular}

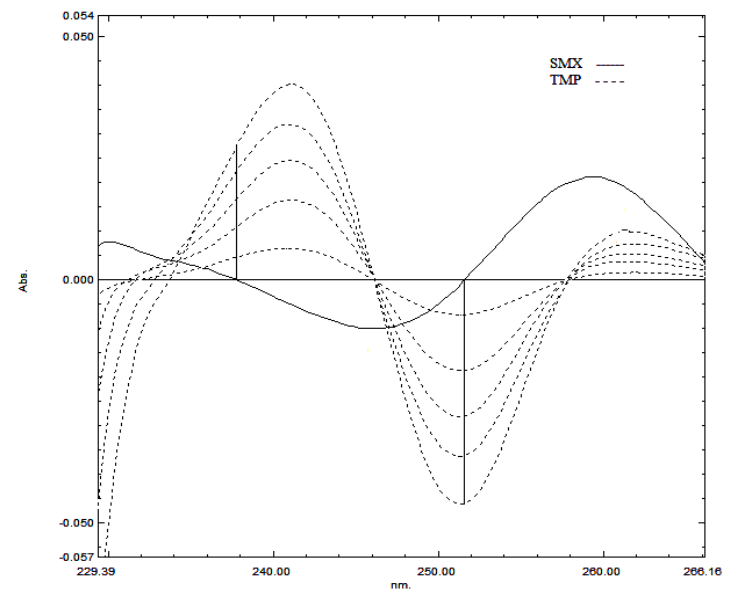

Fig.(7) Fourth derivative zero crossing of (4-25) $\mathrm{mg} / \mathrm{L}$ TMP with(20)mg/L SMX.

Table (7)

The relative error and recovery of TMP in the presence of $S M X$ using $D^{4}$ spectrum zero crossing at valley $251.5 \mathrm{~nm}$.

\begin{tabular}{||c||c||c||c||}
\hline $\begin{array}{c}\text { TMP and SMX } \\
\text { mixtures }\end{array}$ & $\begin{array}{c}\text { TMP } \\
\text { found }^{*} \\
\text { mg/L }\end{array}$ & $\begin{array}{c}\text { Relative } \\
\text { error\% }\end{array}$ & $\begin{array}{c}\text { Recovery } \\
\text { \% }\end{array}$ \\
\hline \hline 30 TMP+0 SMX & $\mathbf{2 9 . 6 7 6}$ & $\mathbf{- 1 . 0 8}$ & 98.92 \\
\hline \hline 20 TMP+0 SMX & $\mathbf{1 9 . 4 7}$ & $\mathbf{- 2 . 6 5}$ & 97.35 \\
\hline \hline 10 TMP+0 SMX & $\mathbf{9 . 7 2 3}$ & $\mathbf{- 2 . 7 7}$ & 97.23 \\
\hline \hline 4 TMP + 0 SMX & $\mathbf{3 . 9 6 7}$ & $\mathbf{- 0 . 8 2}$ & 99.18 \\
\hline \hline 4 TMP+15 SMX & $\mathbf{3 . 9 9 6}$ & $\mathbf{- 0 . 1 0}$ & 99.90 \\
\hline \hline 4 TMP+20 SMX & $\mathbf{4 . 0 2 4}$ & $\mathbf{0 . 6 0}$ & 100.60 \\
\hline \hline 4 TMP+25 SMX & $\mathbf{4 . 0 2 4}$ & $\mathbf{0 . 6 0}$ & 100.60 \\
\hline \hline 2 TMP+20 SMX & $\mathbf{1 . 9 4 6}$ & $\mathbf{- 2 . 7 0}$ & 97.30 \\
\hline \hline 4 TMP+20 SMX & $\mathbf{4 . 0 2 4}$ & $\mathbf{0 . 6 0}$ & 100.60 \\
\hline \hline 6 TMP+20 SMX & 5.933 & -1.12 & 98.88 \\
\hline \hline
\end{tabular}

*Each concentration represents an average of at least three measurements. 
Table (8)

The relative error and recovery of TMP in the presence of $S M X$ using $D^{4}$ spectrum zero crossing at peak $237.6 \mathrm{~nm}$.

\begin{tabular}{||c||c|c||c||}
\hline $\begin{array}{c}\text { TMP and SMX } \\
\text { mixtures }\end{array}$ & $\begin{array}{c}\text { TMP } \\
\text { found } \\
\text { mg/L }\end{array}$ & $\begin{array}{c}\text { Relative } \\
\text { error\% }\end{array}$ & $\begin{array}{c}\text { Recovery } \\
\text { \% }\end{array}$ \\
\hline \hline 30 TMP+0 SMX & $\mathbf{2 9 . 6 5 2}$ & $\mathbf{- 1 . 1 6}$ & 98.84 \\
\hline \hline 20 TMP+0 SMX & $\mathbf{2 0 . 2 5 4}$ & $\mathbf{1 . 2 7}$ & 101.27 \\
\hline \hline 10 TMP+0 SMX & $\mathbf{9 . 8 8 6}$ & $\mathbf{- 1 . 1 4}$ & 98.86 \\
\hline \hline 4 TMP + 0 SMX & $\mathbf{3 . 8 8 7}$ & $\mathbf{- 2 . 8 3}$ & 97.18 \\
\hline \hline 4 TMP+15 SMX & $\mathbf{3 . 9 3 2}$ & $\mathbf{- 1 . 7 0}$ & 98.30 \\
\hline \hline 4 TMP+20 SMX & $\mathbf{3 . 9 3 2}$ & $\mathbf{- 1 . 7 0}$ & 98.30 \\
\hline \hline 4 TMP+25 SMX & $\mathbf{3 . 9 3 2}$ & $\mathbf{- 1 . 7 0}$ & 98.30 \\
\hline \hline 4 TMP+20 SMX & $\mathbf{3 . 9 3 2}$ & $\mathbf{- 1 . 7 0}$ & 98.30 \\
\hline \hline 6 TMP+20 SMX & 5.974 & -0.43 & 99.57 \\
\hline
\end{tabular}

*Each concentration represents an average of at least three measurements.

\section{Interferences study}

To find an effect of matrix constituents on the results of determination, comparative analysis was carried out for standard solution containing active components at concentrations (20SMX+4TMP) $\mathrm{mg} / \mathrm{L}$ comparable to those of the analyzed drug contain the same concentration, they show the same normal spectra Fig.(8).

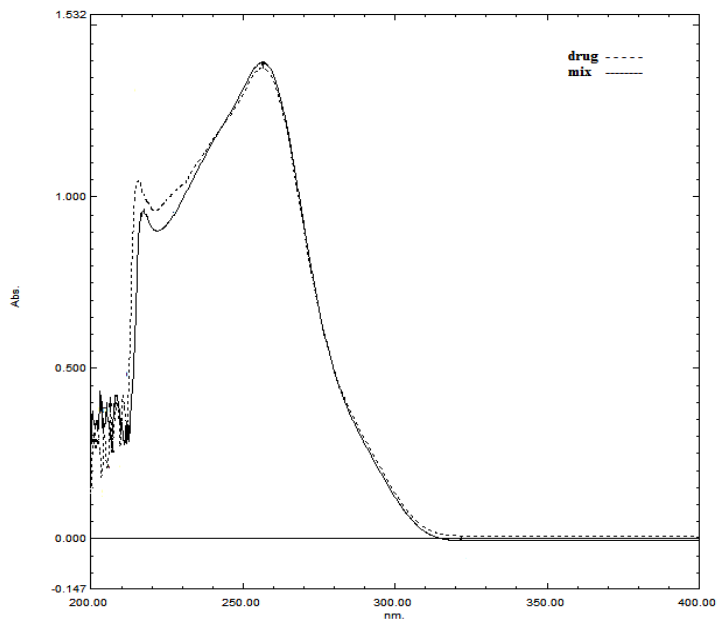

Fig. (8) Normal spectra for analyzed preparation.
Analysis of Pharmaceutical Sample:

METHOPRIM and TRIMOL samples with constant concentration $(20 \mathrm{mg} / \mathrm{L})$ of SMX and ( $4 \mathrm{mg} / \mathrm{L})$ of TMP was measured using the methods listed in Table (9) for determination each of Sulphamethoxazole in the presence of Trimethoprim using; $\mathrm{D}^{4}$ at peak $257.8 \mathrm{~nm}$, and for Trimethoprim in the presence of Sulphamethoxazole using; $\mathrm{D}^{4}$ spectrum at valley $251.5 \mathrm{~nm}$.

Results for the analysis of standard drugs were compared with British pharmacopoeia method $^{(1,11)}$ using $\mathrm{F}$ test. As it is shown in Table (10), a good agreement was observed between the proposed method and standard method.

The analytical method was accepted according to the tabulated value of $(F)$ is greater than the calculated value. 
Table (9)

The pharmaceutical sample relative error, recovery, Standard deviation, statistical analysis and RSD for each method used to determine SMX and TMP in the drug.

\begin{tabular}{|c|c|c|c|c|c|c|c|c|c|c|}
\hline \multicolumn{2}{|c|}{ Drug } & \multicolumn{2}{|r|}{ Method } & \multirow{2}{*}{$\begin{array}{c}\begin{array}{c}\text { Conc. } \\
m g / L\end{array} \\
20\end{array}$} & \multirow{2}{*}{$\begin{array}{c}\begin{array}{c}\text { Found } \\
\text { mg/L }\end{array} \\
17.880\end{array}$} & \multirow{2}{*}{$\begin{array}{c}E r \% \\
-10.596\end{array}$} & \multirow{2}{*}{$\frac{R e \%}{89.404}$} & \multirow{2}{*}{$\frac{\delta_{n-1}}{0.029}$} & \multirow{2}{*}{$\frac{R S D}{0.165}$} & \multirow{2}{*}{$\begin{array}{c}\mu=x \pm(t \delta) / \sqrt{n} \\
17.880 \pm 0.036\end{array}$} \\
\hline$\sum_{\underline{\underline{m}}}$ & SMX & $D^{4}$ & Peak $=257.8$ & & & & & & & \\
\hline 넬 & TMP & $D^{4}$ & Valley $=251.5$ & 4 & 3.209 & -19.77 & 80.23 & 0.039 & 1.241 & $3.209 \pm 0.049$ \\
\hline & SMX & $D^{4}$ & Peak $=257.8$ & 20 & 20.972 & 4.864 & 104.864 & 0.139 & 0.663 & $20.972 \pm 0.172$ \\
\hline$\overline{\tilde{F}}$ & TMP & $D^{4}$ & Valley $=251.5$ & 4 & 3.875 & -3.120 & 96.880 & 0.241 & 6.243 & $3.875 \pm 0.300$ \\
\hline
\end{tabular}

* Each concentration is the average at least for five measurements.

Table (10)

Comparison with British pharmacopoeia method using F test, Standard deviation for SMX and TMP is $(0.543$ and 0.428$)$ respectively.

\begin{tabular}{|c|c|c|c|c||c||}
\hline Standard & \multicolumn{2}{|c||}{ Method } & $\boldsymbol{\delta}_{\boldsymbol{n}-\boldsymbol{1}}$ & $\boldsymbol{F}_{\text {cal. }}$ & $\boldsymbol{\mu}=\boldsymbol{x} \pm(\boldsymbol{t} \boldsymbol{\delta}) / \sqrt{\boldsymbol{n}}$ \\
\hline \hline 20SMX+4TMP & $\mathrm{D}^{4}$ & Peak $=257.8$ & 0.202 & 2.688 & $19.977 \pm 0.251$ \\
\hline \hline $20 \mathrm{SMX}+4 \mathrm{TMP}$ & $\mathrm{D}^{4}$ & Valley $=251.5$ & 0.247 & 1.732 & $4.024 \pm 0.307$ \\
\hline
\end{tabular}

$F_{\text {tab }}$ for $n_{1}=6, n_{2}=5$ is equal to (6.26).

\section{Conclusions}

A fast and accurate method for determination of sulphamethoxazole and trimethoprim was developed by using derivative spectrophotometry. The advantage of this method is that both constituents can be determined directly in a single sample without the need to be separated. It was also found that $\mathrm{D}^{4}$ is used for determining the drugs in tablets.

\section{References}

[1] British Pharmacopoeia, "Medicinal and pharmaceutical Substances", published by (MHRA), 1 \& 2, 5729, 6201, 2009.

[2] Goodman L. S., and Gilman A., "Pharmacological Basis of Therapeutics", MacMillan. New York, Toronto, London, 1115, 1975.

[3] Jose R., Maximiliano M., Marcela H., Adriana M. and Juan C., "simultaneous determination of trimethoprim and sulphamethoxazole in immediate-release oral dosage forms by first order derivative spectroscopy: application to dissolution studies", International Journal of Pharmacy and Pharmaceutical Sciences, 5(4), 505510, 2013.
[4] Amini H. and Ahmadiani A. "Rapid and simultaneous determination of sulphamethoxazole and trimethoprim in human plasma by high-performance liquid chromatography" Journal of Pharmaceutical and Biomedical Analysis, 43(3), 1146-1150, 2007.

[5] Sayar E., Sahin S., Cevheroglu S. and Hincal A. A., "Development and validation of an HPLC method for simultaneous determination of trimethoprim and sulphamethoxazole in human plasma" European Journal of Drug Metabolism and Pharmacokinetics, 35(1-2),41-46, 2010.

[6] Okine N. N. A., Asare-Nkansah S. and Acheampong A., "Simultaneous Determination of Sulphamethoxazole and Tri-methoprim in Co-trimoxazole Tablets using RP-LC Analysis", Journal of Scienceand Technology, 26(3), 66-74, 2006.

[7] Agbaba D., Radovic A., Vladimirov S. and Zivanov-Stakic D., "Simultaneous TLC Determination of Co-trimoxazole and Impurities of Sulfanilamide and Sulfanilic Acid in Pharmaceuticals", Journal of 
Chromatographic Science, 34, 460-464, 1996.

[8] Silva I. S. d., Vidal D. T. R., Lago C. L. and Angne L., "Fast simultaneous determination of trimethoprim and sulphamethoxazole by capillary zone electrophoresis with capacitively coupled contactless conductivity detection", Journal of Separation Science, 36(8), 1405-1409, 2013.

[9] Andrade L. S., Rocha-Filho R. C., Cass Q. B. and Fatibello-Filho O., "Simultaneous Differential Pulse Voltammetric Determination of Sulphamethoxazole and Trimethoprim on a Boron-Doped Diamond Electrode", Electroanalysis, 21(13), 14751480, 2009.

[10] Andrade L. S., Rocha-Filho R. C., Cassa Q. B. and Fatibello-Filho O., "A novel multicommutation stopped-flow system for the simultaneous determination of sulphamethoxazole and trimethoprim by differential pulse voltammetry on a borondoped diamond electrode" Analytical Methods, 2(4), 402-407, 2010.

[11] Givianrad M. H. and Mohagheghian M., "Net Analyte Signal Standard Additions Method for Simultaneous Determination of Sulphamethoxazole and Trimethoprim in Pharmaceutical Formulations and Biological Fluids", E-Journal of Chemistry, 9(2), 680-692, 2012.

[12] Shamsa F. and Amani L., "Determination of Sulphamethoxazole and Trimethoprim in Pharmaceuticals by Visible and UV Spectrophotometry" Iranian Journal of Pharmaceutical Research,1(1),31-36, 2006.

[13] Sohrabi M. R., Fathabadi M. and Nouri A. H., "Simultaneous spectrophotometric determination of sulphamethoxazoleand trimethoprim in pharmaceutical preparationsby using multivariate calibration methods", Journal of Applied Chemical Researches, 3(12), 47-52, 2010.

[14] Zimmer L. and Czarnecki W., "Derivative spectrophotometric method for simultaneous determination of sulfadimidine and trimethoprim", 13(1, 3), 27-36, 2010.

[15] Adome1 R.O. and Balyejjusa S., "The optimum $\mathrm{pH}$ for the derivative spectrophotometric determinationof cotrimoxazole in binary mixture" pyridines

African Health Sciences, 2(3), 114-117, 2002.

[16] Kargosha K. and Ahmadi S. H., "Simultaneous Determination of Sulphamethoxazole and Trimethoprim in Co-Trimoxazole Tablets by First-Derivative FTIR Spectrometry", Analytical Letters, 32(8), 1613-1626, 1999.

[17] K.H. Al-Saidi, N.S. Nassory and S.A. Maki, "Spectrophotometric determination of binary mixture of some B-lactam antibiotics", JNUS, 12(3), 33-44, 2009.

[18] Salem H., "Spectrochemical Methods for the Determination of Sildenafil Citrate (Viagra) in Bulk Powder and in Pharmaceutical Dosage Form", J. Appl. Sci., 8(1), 28-43, 2006.

[19] Mohamed A.E., Salem H. and Maher E., "Spectrophotometric Determination of Binary Mixtures of Prednisolone with some Antibiotics", Thai J. Pharm. Sci., 30(1), 6381, 2006.

[20] Mohamed A.E. and Salem H., "Determination of antihypertensive mixtures by use of a chemo-metrics assisted spectrophotometric method." Anal. Bioanal. Chem., 382(4), 1066-1072, 2005.

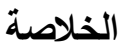

$$
\begin{aligned}
& \text { في هذا البحث تم تقدير هذه المركبات أنبا باستخدام } \\
& \text { المشتقات الطيفية للأدوية (الاولى والثانية والثالثة والرابعة). } \\
& \text { على شكل أمزجة ثنائية للأدوية بواسطة نطبيق التقاطع }
\end{aligned}
$$

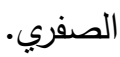

$$
\begin{aligned}
& \text { تم تعيين السلفاميثاكسازول والترايميثوبريم انيا في الادوية } \\
& \text { باستخدام المشتقة الرابعة في (257.8nm) و (251.5nm) } \\
& \text { للسلفاميثاكسازول و الترايميثوبريم على التوالي. وكان منحني } \\
& \text { المعايرة بمعامل ارتباط r لا يقل عن (0.9992 و 0.9995) }
\end{aligned}
$$

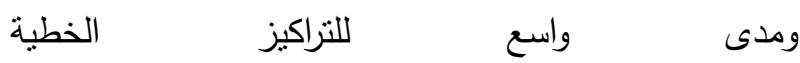

$$
\begin{aligned}
& \text { وخطا نسبي (-2-25 mg/L) }
\end{aligned}
$$

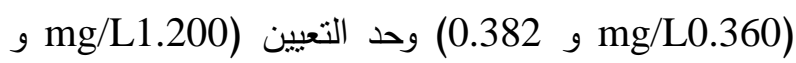

$$
\begin{aligned}
& \text { 1.275) على التوالي بدون تداخل بين مكونات الادوية. }
\end{aligned}
$$

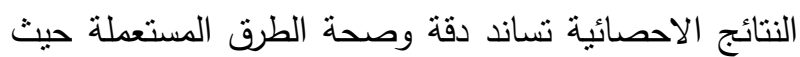

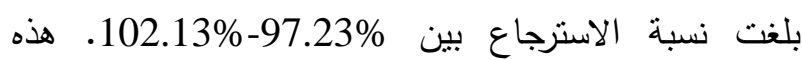

$$
\begin{aligned}
& \text { الطريقة سهلة لا تحتاج الى فصل أو أي معاملة. }
\end{aligned}
$$

